in strength and durability of construction. ... While picking up relics a gentleman of another party picked up a ferrotype of a very pretty girl remarking as he did so "the possessor must have fought hard for her."'

More fortifications completed the sight seeing, and the party returned home "pleased with the trip ... and looking all the better for a little sunburn or rather tan."

\title{
The Purchase of Monte Libretto by the Barberini
}

A VERY valuable collection of business papers of the Barberini and Sciarra-Colonna families of Rome was acquired by the Society last year through the generosity of Mr. Edward J. Frost of Boston. Among the documents is a huge ledger relating to the administration of Monte Libretto, a village in the Sabine Hills, which the Barberini owned for more than a century. A photograph of this volume appeared in an earlier Bulletin. The entries in the ledger are for the closing years of the eighteenth century.

Some interesting, though fragmentary, information concerning the purchase of Monte Libretto by the Barberini has been discovered in an old pamphlet sent by an Italian friend of the Society. In I644 Taddeo Barberini arranged to purchase the estate of Monte Libretto from the Orsini family. Two experts were chosen to determine the value of the estate. At the same time a third man was appointed, whose estimate was to be accepted in case the first two appraisers did not agree. Such was the case and the third party, Pietro Vannini, was called upon. He estimated the total value of the estate at $1,160,000$ scudi, on the basis of which estimate the Barberini were to pay 26,000 scudi. This was in accordance with an agreement that the purchase price should be fixed at $2 \frac{1}{4}$ per cent of the value of the estate including all the sources of revenue. Various interpretations might be placed upon this agreement, but it is hoped that the facts will be clear when further study is made.

Vannini's report was not based upon an itemized account of the possessions, revenues, etc. of the estate, and Maffeo Barberini, son and heir of Taddeo, the purchaser, refused to pay the amount which was due the Orsini according to Vannini's appraisal. The case was brought before the Papal Court in $165^{2}$ and had not yet 
been settled in 1656 . Four documents dated from 1654 to 1656 which deal with the case are published in the above-mentioned pamphlet. The court ordered Vannini to make an itemized report of all the buildings, holdings, revenues, etc. of the estate under pain of excommunication. The first threat had no effect and as late as March, 1656 , he was granted one more month in which to present the desired appraisal. Further court documents are missing and hence the outcome of the suit is unknown.

The situation is an interesting one. Did Vannini make the required report and were the Barberini satisfied with the new figures? Or did the court compel Maffeo to pay against his will? Since the Barberini entered into full possession of Monte Libretto, we presume that the Orsini, the former proprietors were eventually paid. It is hoped that some volume of the Barberini Collection will reveal the conclusion to this unfinished tale of the manner in which the purchase of a large estate was made three hundred years ago.

\section{Advance Notice}

Attention is called to a contribution by Dr. Arthur Borak of the School of Business, University of Minnesota, which will appear in the November publication of the Fournal of Economic and Business History. It deals with the various steps taken in the reorganization of the Chicago, Milwaukee, St. Paul and Pacific Railway, which have occupied the attention of the public for the past ten years. The article is somewhat over thirty pages in length.

It has been suggested that many of our members may be interested in securing extra copies for distribution among their friends or for the information of their organizations.

A sufficient number of extra copies of this one article has already been ordered to justify the Society in printing it in separate pamphlet form, and if any of our members desire a quantity of these pamphlets, we shall be glad to place orders on file for them. These pamphlets will cost fifteen cents per copy and orders for them should be placed before September first in order that suitable arrangements with the publishers may be made for their production. 